\title{
Erosion and sediment transport modelling in Northern Puglia watersheds
}

\author{
F. Gentile, T. Bisantino \& G. Trisorio Liuzzi \\ PROGESA Department, University of Bari, Italy
}

\begin{abstract}
In the Puglia region (southern Italy) heavy storms trigger high suspended sediment transport in water courses, accelerate soil and nutrients loss, and adversely affect biodiversity. In addition, high siltation in reservoirs reduces the water-holding capacity and creates severe problems of water availability for agriculture, which still plays an important role in the local economy. In the study area, suspended load data derive from continuous monitoring in the Carapelle torrent (2007-2008) and from hand-sampling in the Salsola sub-catchment of the Candelaro torrent (1970-1984). Recorded data of total streamflow are also available for both torrents. The high temporal resolution data were used to analyze the sediment transport dynamics and to evaluate the predictive accuracy of the Annualized AGricultural Non-point Source (AnnAGNPS) pollution model at the event scale. The historical data were used to test the reliability of the model for long-term periods and to compare the performances of medium and small size watersheds.

Keywords: soil erosion, sediment transport, AnnAGNPS model, continuous monitoring.
\end{abstract}

\section{Introduction}

During the past four decades, different simulation models have been developed to estimate surface runoff, sediment, nutrient and pollutant transport processes. The widely used water quality models include ANSWERS, Beasley et al. [1], CREAMS, Knisel [2], GLEAMS, Leonard et al. [3], AnnAGNPS, Bingner and Theurer [4], and SWAT, Arnold et al. [5]. Among these models the Annualized Agricultural Non-Point Source AnnAGNPS pollution model has a structure that balances complexity and parameterization as it uses empirical and quasi- 
physically based algorithms to predict runoff volume, peak flow rate, sediment and nutrient yield. AnnAGNPS was developed for simulation in ungaged agricultural watersheds, with the purpose of evaluating the influence of nonpoint source pollution on surface water and groundwater quality.

The model computes runoff using the SCS Curve Number method, which was originally developed for agricultural sites as an infiltration loss model. Using theoretical arguments it is possible to apply the SCS-CN method for hydrologic simulation to any basin (Mishra and Singh [6]). The method has several advantages over others because it is a simple conceptual method and is well supported by empirical data. AnnAGNPS has been calibrated, validated, and applied for runoff and sediment yield losses from watersheds in different geographic locations, conditions and management practices.

Applying AnnAGNPS and ANSWERS models (Walling et al. [7]) compared, firstly, observed and predicted runoff and sediment output data for individual storm events monitored at the basin outlets and, secondly, information on the spatial pattern of soil redistribution within the catchments derived from 137Cs measurements. The results obtained indicate that catchment outputs simulated by both models are reasonably consistent with the recorded values, although the AGNPS model appears to provide closer agreement between observed and predicted values. Comparison of the catchment sediment delivery ratios and the pattern of soil redistribution in individual fields predicted by the models with equivalent information derived from $137 \mathrm{Cs}$ measurements indicates that the AGNPS model provides more meaningful predictions of erosion and sediment yield than the ANSWERS model.

AnnAGNPS and SWAT models were calibrated in Red Rock Creek watershed and validated in Goose Creek watershed, both sub-watersheds of the Cheney Lake watershed. Forty-five months (1997-2000) of monthly measured flow and water quality data were used to evaluate the two models that performed well for surface flow and sediment yield (Parajuli et al. [8]).

AnnAGNPS reliability was assessed in the Mississippi Delta MSEA watershed (Yuan et al. [9]). Using no calibrated parameters, the underestimation of runoff for extreme events was observed, although the relationship between simulated and observed data on an event basis was significant $\left(\mathrm{R}^{2}=0.9\right)$. In contrast, the lower $\mathrm{R}^{2}$ of 0.5 for event comparison of predicted and observed sediment yields demonstrated that the model was not best suited for short-term individual event sediment prediction. This may be due to the use of the Revised Universal Soil Loss Equation (RUSLE) within AnnAGNPS, and of parameters derived from long-term average annual soil loss estimates. The agreement between monthly average predicted and observed sediment yield had an $\mathrm{R}^{2}$ of 0.7 . Three-year predicted total runoff was $89 \%$ of the observed, and three-year predicted total sediment yield was $104 \%$ of the observed.

In this paper, the model is applied to the $506 \mathrm{~km}^{2}$ Carapelle watershed and the $43 \mathrm{~km}^{2}$ Salsola sub-catchment, which are predominantly agricultural with major crops of durum wheat. Flow regime is torrential and floods event are mainly associated with intensive, short-term rainfall. Soil erosion that affects these basins is an important indicator of soil productivity, while sediment yield 
influences water quality in agriculture. The sediment transport is mainly characterised by suspended materials.

The major objectives of this work are: to evaluate the ability of AnnAGNPS in simulating runoff and sediment yield at event scale in calibrated and validation modes; to compare the model estimation of runoff at event scale with the long-term simulation; to evaluate the model for runoff and sediment yield comparing the response of a medium size watersheds to that of a small size one in the same area.

\section{Material and methods}

\subsection{The AnnAGNPS model}

AnnAGNPS is a continuous simulation watershed-scale model developed on the single-event model AGNPS. AnnAGNPS simulates quantities of surface water, sediment, nutrients, and pesticides leaving the land areas and their subsequent travel through the watershed. AnnAGNPS divides the watershed into homogenous drainage areas, which are then integrated together by simulated rivers and streams, routing the runoff and pollutants from each area downstream. The hydrology of the model is based on a simple water balance approach that considers runoff, evapotranspiration and percolation, maintaining a water budget for the 2-layer soil system. The following equation is used to determine soil moisture for each time step in a day:

$$
S M_{t+1}=S M_{t}+\frac{W I_{t}-Q_{t}-P E R C_{t}-E T_{t}-Q_{\text {lat }}-Q_{\text {tile }}}{Z}
$$

where:

$\mathrm{SM}=$ moisture content for each soil layer at the beginning of time period (fraction),

$\mathrm{SM}_{\mathrm{t}+1}=$ moisture content for each soil layer at the end of time period (fraction), $\mathrm{WI}_{\mathrm{t}}=$ water input, consisting of precipitation or snowmelt plus irrigation water $(\mathrm{mm})$,

$\mathrm{Q}_{\mathrm{t}}=$ surface runoff $(\mathrm{mm})$,

$\mathrm{PERC}_{\mathrm{t}}=$ percolation of water out of each soil layer $(\mathrm{mm})$,

$\mathrm{ET}_{\mathrm{t}}=$ potential evapotranspiration $(\mathrm{mm})$,

$\mathrm{Q}_{\text {lat }}=$ subsurface lateral flow ( $\left.\mathrm{mm}\right)$,

$\mathrm{Q}_{\text {tile }}=$ tile drainage flow $(\mathrm{mm})$,

$\mathrm{Z}=$ thickness of soil layer $(\mathrm{mm})$,

$\mathrm{t}=$ the time period.

The influx is a function of effective rainfall less any retention required to wet the surface and fill depressions and any runoff determined by the day's runoff curve number. The initial infiltration into the control volume is predicted by the runoff curve number and is assumed to be a function of saturated flow into the control volume via worm holes and vertical cracks as well as flow through the interstices. 
The flux out is the sum of the day's: (a) soil moisture leaving the bottom of the control volume; (b) lateral or quick return flow which would include tile drainage if present; (c) evapotranspiration which is calculated according to the FAO procedure.

The soil moisture movement within the control volume is determined using unsaturated flow equations for vertical percolation through the soil interstices. Percolation occurs at the rate of the hydraulic conductivity corresponding to the soil moisture content, calculated according to the Brooks-Corey equation.

Each day a daily runoff curve number is calculated based upon the given RCN II and the available soil moisture. Available soil moisture is the water content between the wilting point and field capacity. The daily runoff curve number is computed according to an exponential available soil moisture relationship where AMC I is at the wilting point $(0 \%)$ and AMC II is half way between the wilting point and field capacity (50\%). Tile drains, if present, affect the available soil moisture and its drainage can be a major source of quick return flow that adds directly to the recession leg of the runoff hydrograph.

Water that leaves the bottom of the control volume continues through the vadose zone and eventually becomes the major source of groundwater.

Soil erosion is determined using the Revised Universal Soil Loss Equation (RUSLE). Sediment yield is computed using the HUSLE equation (Theurer and Clarke [10]):

$$
S_{y}=0.22 V_{r}^{0.68} q_{p}^{0.95} K L S C P
$$

where $S_{y}$ is the sediment yield $(\mathrm{t} / \mathrm{ha}), \mathrm{V}_{\mathrm{r}}=$ surface runoff volume $(\mathrm{mm}), \mathrm{q}_{\mathrm{p}}=$ peak rate of surface runoff $(\mathrm{mm} / \mathrm{s}), \mathrm{K}, \mathrm{L}, \mathrm{S}, \mathrm{C}, \mathrm{P}$ are RUSLE factors. All three variables $\left(\mathrm{S}_{\mathrm{y}}, \mathrm{V}_{\mathrm{r}}\right.$, and $\left.\mathrm{q}_{\mathrm{p}}\right)$ are based on unit area; i.e., divided by their drainage area.

Sediment transport is estimated using the Einstein deposition equation with Bagnold transport capacity.

Special components are included to handle concentrated sources of nutrients (feedlots and point sources), concentrated sediment sources (gullies), and added water (irrigation). Output is expressed on an event basis for selected stream reaches and as source accounting (contribution to outlet) from land or reach components over the simulation period. The model can be used to evaluate best management practices (BMPs).

\subsection{Study area}

The Candelaro and Carapelle torrents originate in the Apennine mountains and cross the Tavoliere flood plain before flowing into the Adriatic sea, fig.1. The watersheds are characterised by clayey-sandy Plio-Pleistocene sediments in the alluvial fan and by flyschoid formations in the mountainous areas, which are subject to erosion. The plain and the low hilly areas are mainly used for cultivation $(85 \%)$ of durum wheat, high diversity of vegetables and olive groves, whereas forests and pasture prevail in the higher slopes. The climate is typically Mediterranean, with rainfalls ranging from 450 to $800 \mathrm{~mm} /$ year and average temperatures ranging from 10 to $16^{\circ} \mathrm{C}$. 
Table 1: $\quad$ Main characteristics of the Carapelle at Ordona bridge and Salsola at Casanova watersheds.

\begin{tabular}{|c|c|c|c|}
\hline & & Carapelle at Ordona bridge & Salsola at Casanova \\
\hline Watershed area & $\mathrm{km}^{2}$ & 506.2 & 44.1 \\
\hline Maximum altitude & $\mathrm{m}$ a.s.l & 1075.0 & 1025.0 \\
\hline Average altitude & $\mathrm{m}$ a.s.l. & 466.0 & 432.0 \\
\hline Minimum altitude & $\mathrm{m}$ a.s.l & 120.0 & 189.0 \\
\hline Main channel length & $\mathrm{km}$ & 52.2 & 17.0 \\
\hline Main channel slope & $\%$ & 1.8 & 4.9 \\
\hline Mean watershed slope & $\%$ & 8.2 & 6.1 \\
\hline
\end{tabular}
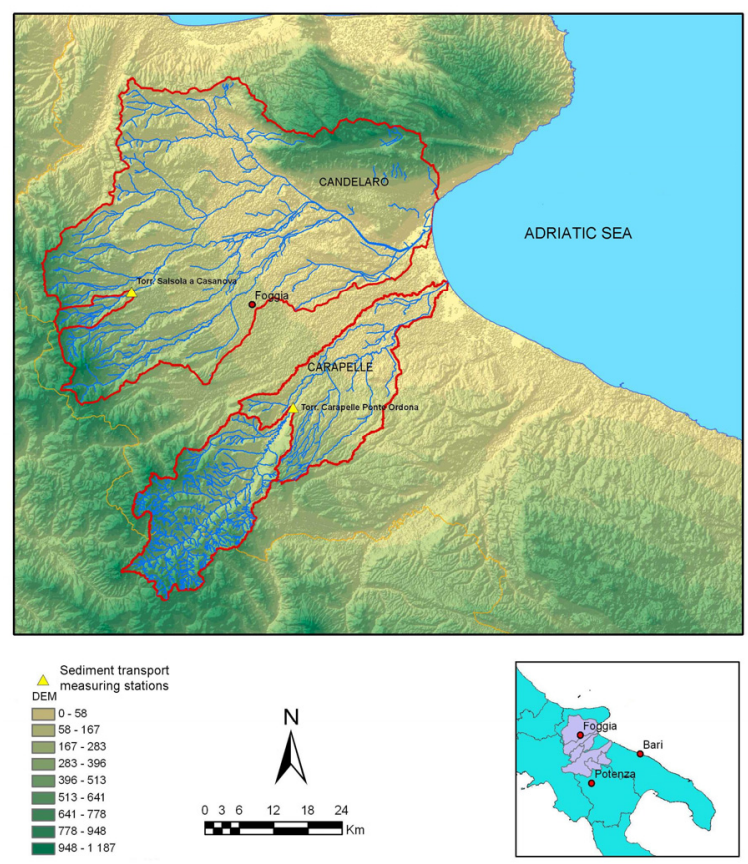

Figure 1: The Carapelle and Candelaro watersheds and relative subwatersheds with the mouth at the sediment transport stations.

The erosion processes (rill and gully erosion) that affect the watersheds are mainly located on the hillslopes. During heavy storms these processes trigger high-suspended sediment transport, accelerate soil and nutrients loss, pollution in water courses and adversely affect biodiversity. Deforestation has increased the phenomenon of instability, landslides and unstable slopes, consequently runoff events cause high rates of sediment transport. Additionally high siltation in reservoirs reduces water-holding capacity and creates severe problems of water availability for agriculture and urban use. Typically rural farmers have problems related to water shortage. 
Data sources for the model inputs included the NASA Digital Elevation Model for topography, the ACLA2 regional project (Caliandro et al. [11]), for soil data and the CORINE Land Cover cropland data layer.

\subsection{Streamflow and suspended sediment data}

Streamflow data for both study watersheds were available from the Italian Hydrological Service (IHS) gauging stations. Baseflow separation is required for numerous widely used hydrological and erosive models, such as AnnAGNPS, and it must be considered also in monthly models (Mouelhi et al. [12]). In this work the following filtering algorithms (Eckhardt [13]), for separating baseflow from total streamflow was used:

$$
b_{k}=\frac{\left(1-B F I_{\max }\right) a b_{k-1}+(1-a) B F I_{\max } Q_{t}}{1-a B F I_{\max }}
$$

where $b_{k}$ is the base flow at time step $k ; b_{k-1}$ is the base flow at the previous time step; $Q_{k}$ is the measured total flow; BFImax is a constant that can be interpreted as the maximum baseflow index; $a$ filtering coefficient. The coefficient BFImax or base flow index gives the long-term mean ratio of base flow to total runoff. $B F I_{\max }$ was calculated using the hydrograph recession curve analysis and the optimization module developed by Kyoung et al. [14].

The spatial distribution of rainfall data were assessed using the Thiessen weighting procedure for the closest rain gauges to the watersheds.

Continuous sediment load data derived from the monitoring station set up in the Carapelle torrent at Ordona-Castelluccio dei Sauri bridge. The station is equipped with an infrared optical probe (Hach-Lange SOLITAX Hs-line), chosen in view of its capability to measure high solid concentration and to reduce watery medium and light interferences. The probe measures suspended sediment coupling backscattering and nephelometric photodetectors. The probe was preliminary tested in laboratory using mixtures of varying granulometric concentration to evaluate its functional capacity and to assess the effects of the different solid fractions on the measurements. The instrument was field calibrated during the flood periods 2007-2009 (Gentile et al. [15]). Figure 2 shows the relation between sensor output and concentration as a result of previous calibration.

Afterwards, the instrument was tested in the field through a calibration stage and the verification of the instrument housing. The most relevant flood events were then considered and the suspended sediment concentration, monitored at half-hourly scale, was plotted versus discharge to analyze the sediment transport dynamic. The recorded discharges (Q) and sediment concentrations (SSCs) for the period 2007-2008 are reported in figures 3-4.

Monthly total streamflow are also available for the Carapelle watershed for the period 1986-1996, while yearly sediment load and monthly total streamflow data derive from IHS measurements for the Salsola sub-catchment (1970-1984). 
Monitoring, Simulation, Prevention and Remediation of Dense and Debris Flows III 205

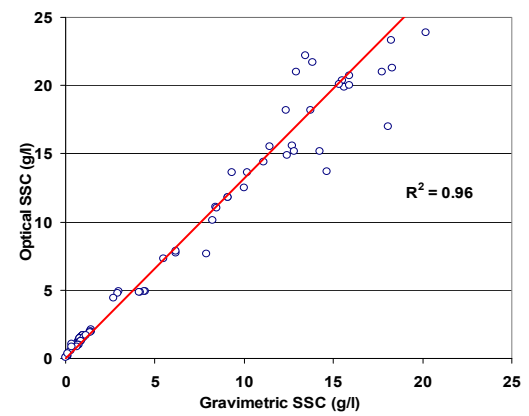

Figure 2: Relationship between sensor output and concentration.
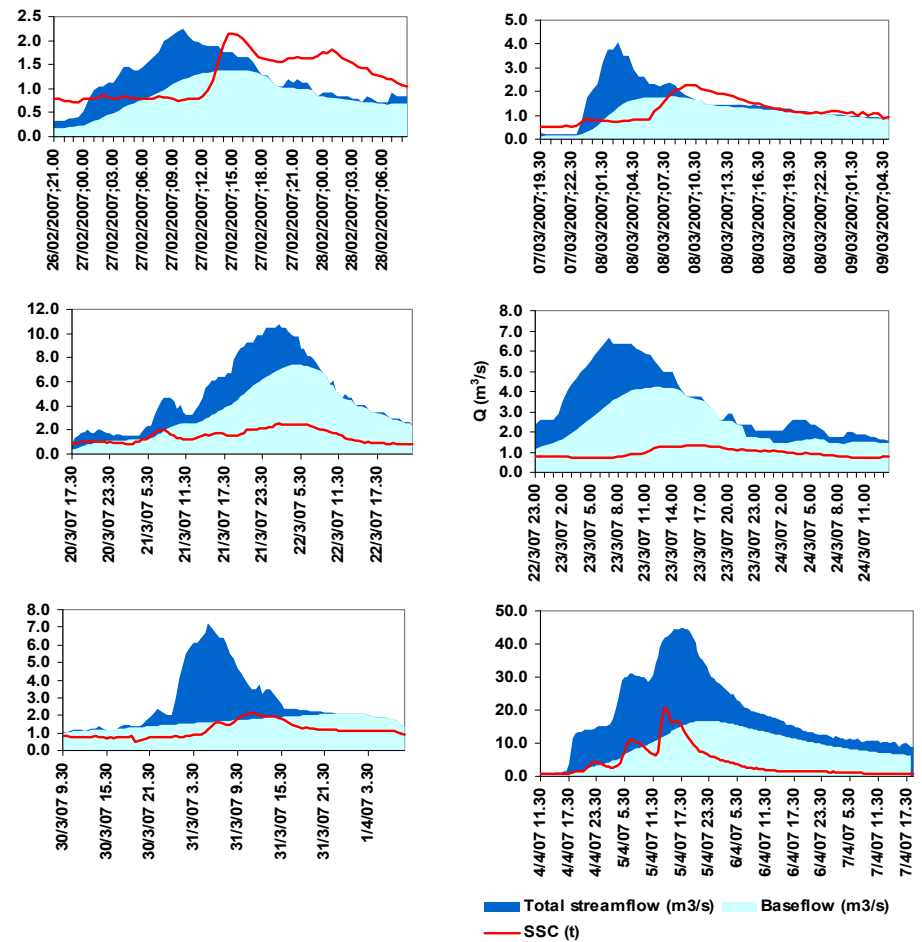

Figure 3: Flood events monitored in 2007 and used for the calibration of the AnnAGNPS model. 

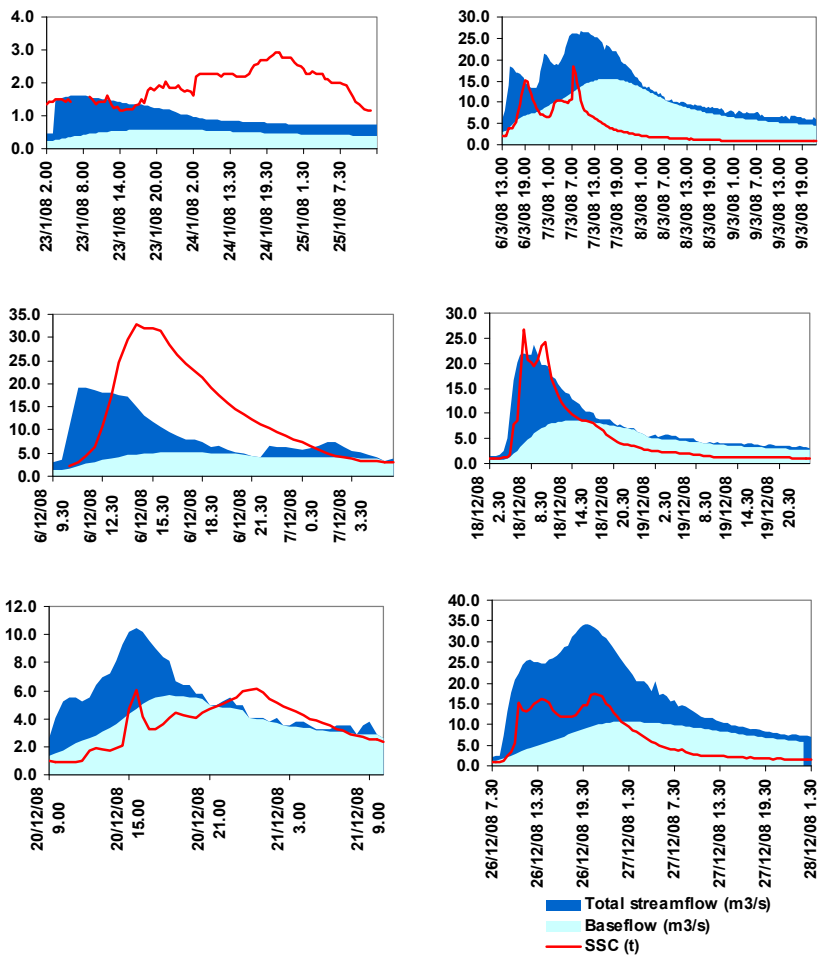

Figure 4: Flood events monitored in 2008 and used for the validation of the AnnAGNPS model.

Table 2: $\quad$ Initial curve number values.

\begin{tabular}{|l|c|c|c|c|}
\hline Cover type & \multicolumn{5}{|c|}{ Initial curve numbers for hydrologic soil groups } \\
\hline & A & B & C & D \\
\hline Cropland & 72 & 81 & 88 & 91 \\
\hline Fallow & 76 & 85 & 90 & 98 \\
\hline Rangeland & 35 & 56 & 70 & 77 \\
\hline Forest & 43 & 65 & 76 & 82 \\
\hline Pasture & 49 & 69 & 79 & 84 \\
\hline Urban & 89 & 92 & 94 & 95 \\
\hline
\end{tabular}

\section{Results}

\subsection{Model preprocessing}

The model preprocessing regarded the definition of the Curve Number data (tab.2) for each defined field type (cropland, fallow, rangeland, forest, pasture and urban) and for each Hydrologic Soil Group (A, B, C, D). The CN values were estimated for different land uses of the watersheds for both the watersheds 
and the weighted CNs for different cells of the agricultural watersheds were calculated.

The rainfall erosivity factor $\mathrm{R}$ was estimated based on the mean monthly precipitation of the period 1979-1999 according to Ferro et al. [16]. The value of $\mathrm{R}$ after calculations is $960.70 \mathrm{MJ} \mathrm{mm} \mathrm{ha}^{-1}$ year $^{-1}$.

The Lal and Elliot [17] equation was used to estimate the soil erodibility factor K. Eight types of soils were identified, whose erodibility factors are shown in table 3. Soil types were used to evaluate the hydraulic soil properties such as the saturated hydraulic conductivity, field capacity and wilting point (Saxton and Rawls [18]).

The Crop data required by the model regard the units harvested, surface and subsurface decomposition, crop residue, root mass, canopy cover, management scheduling and operation. The management schedule of wheat was assumed (tab. 4) as cereals represent $84 \%$ of the total surface. Croplands contribute with relative low soil erosion. One factor contributing to the erosion of croplands is the amount annual disturbance. In this simulation, three disturbances have been chosen (plough, harvest and semi-deep drill).

The crop management factor $\mathrm{C}$ for each period was calculated based on land use, canopy cover, surface cover and surface roughness and soil moisture conditions. The P-factor was supposed to be equal to 1 since no management operation to reduce erosion has been considered.

Table 3: Soil erodibility factors $\mathrm{K}$ estimated using the soils' physical properties and organic matter content of the European Soil Data Centre (ESDAC).

\begin{tabular}{|l|c|}
\hline Soil structure & K factor $\left(\mathbf{t ~ h ~} \mathbf{~ M J}^{-\mathbf{1}} \mathbf{~ m m}^{-1} \mathbf{)}\right.$ \\
\hline Clay & 0.033 \\
\hline Sandy clay & 0.043 \\
\hline Loam & 0.03 \\
\hline Clay Loam & 0.042 \\
\hline Silty clay & 0.0346 \\
\hline Silty-clay-loam & 0.0271 \\
\hline Loamy-sand-clay & 0.038 \\
\hline Sandy-loam & 0.016 \\
\hline
\end{tabular}

Table 4: $\quad$ Management scheduling and operation for wheat.

\begin{tabular}{|c|c|c|c|c|}
\hline Crop & Event date & Management schedule & Curve number & Management Operation \\
\hline Wheat & $06 / 01 / 01$ & Harvest grain & Fallow & Residue added to surface \\
\hline & & & & Current crop harvested \\
\hline & & & & Call in a new crop growth \\
\hline & $09 / 01 / 01$ & Plough & Fallow & Soil disturbed \\
\hline & & & & Crop planting \\
\hline & $09 / 20 / 01$ & Begin crop growth & Cropland & Call in a new crop growth \\
\hline & $12 / 15 / 01$ & Semi-deep drill & Cropland & Soil surface disturbed \\
\hline
\end{tabular}




\subsection{Model calibration and validation in the Carapelle watershed at event scale}

Hourly streamflow and suspended sediment concentrations were used to calibrate and validate the model at event scale in the Carapelle watershed. A total of 6 events were used for model calibration, while 6 events were used in model validation.

Before the model calibration a preliminary sensitivity analysis (Chouaib [19]), for the most common parameters of the model (storm type, R, K, C and P factors of USLE equation, $\mathrm{CN}$ curve number and MN Manning's roughness coefficient) was carried out. The results pointed out that the $\mathrm{CN}$ coefficient is the most sensitive parameter as it controls runoff volumes while the storm type mainly influences peak discharge. $\mathrm{CN}$ was subjected to calibration varying the retention factor. After the calibration of $\mathrm{CN}$ values, Manning's coefficients were adjusted to fit peak discharge and sediment load.

The comparison of measured and calculated values of peak discharge, runoff volume and total suspended load during the events is shown in table 5. Simulated data were evaluated using statistical indexes, the coefficient of determination $\left(\mathrm{R}^{2}\right)$ and the Nash-Sutcliffe Efficiency Index (NSE). Correlation and agreement between observed and simulated peak flow, runoff and sediment load in the calibration phase is excellent. In the validation phase the model shows good performances for runoff, peak flow and sediment load.

Table 5: $\quad$ Measured and predicted peak discharge, runoff volume and sediment load for calibration and validation periods.

\begin{tabular}{|c|c|c|c|c|c|c|c|}
\hline & \multirow[t]{2}{*}{ Event } & \multicolumn{2}{|c|}{$\begin{array}{c}\text { Peak discharge } \\
\left(\mathrm{m}^{3} / \mathrm{s}\right)\end{array}$} & \multicolumn{2}{|c|}{$\begin{array}{c}\text { Runoff Volume } \\
\left(\mathbf{m}^{3}\right)\end{array}$} & \multicolumn{2}{|c|}{$\begin{array}{l}\text { Sediment load } \\
\text { (t) }\end{array}$} \\
\hline & & Obs & Sim & Obs & Sim & Obs & Sim \\
\hline Calibration & 27207 & 1.1 & 1.3 & 94593 & 50807 & 202 & 586 \\
\hline & 7307 & 2.8 & 2.4 & 106362 & 92315 & 228 & 1048 \\
\hline & 21307 & 4.7 & 4.3 & 271983 & 230529 & 2178 & 2100 \\
\hline & $23 \quad 307$ & 3.3 & 0.2 & 135277 & 7669 & 452 & 43 \\
\hline & 31307 & 5.7 & 11.1 & 189558 & 443321 & 583 & 7820 \\
\hline & $5 \lcm{407}$ & 30.8 & 31.3 & 2896506 & 2826167 & 36124 & 28463 \\
\hline $\mathrm{R}^{2}$ & & \multicolumn{2}{|c|}{0.94} & \multicolumn{2}{|c|}{0.99} & \multicolumn{2}{|c|}{0.91} \\
\hline NSE & & \multicolumn{2}{|c|}{0.94} & \multicolumn{2}{|c|}{0.99} & \multicolumn{2}{|c|}{0.89} \\
\hline Validation & $24 \_1 \_08$ & 1.3 & 0.2 & 112969 & 7528 & 358 & 80 \\
\hline & 6308 & 14.3 & 38.5 & 1339256 & 2044547 & 18232 & 37310 \\
\hline & $6 \_12 \_08$ & 16.9 & 11.5 & 351810 & 429511 & 11336 & 11104 \\
\hline & $18 \_12 \_08$ & 18.4 & 5.0 & 508572 & 20781 & 13065 & 471 \\
\hline & $20 \_12 \_08$ & 5.8 & 3.0 & 145847 & 8175 & 1997 & 135 \\
\hline & $26 \_12 \_08$ & 25.7 & 32.9 & 1573264 & 1719026 & 25503 & 19841 \\
\hline $\mathrm{R}^{2}$ & & \multicolumn{2}{|c|}{0.78} & \multicolumn{2}{|c|}{0.86} & \multicolumn{2}{|c|}{0.74} \\
\hline NSE & & \multicolumn{2}{|c|}{0.54} & \multicolumn{2}{|c|}{0.6} & \multicolumn{2}{|c|}{0.65} \\
\hline
\end{tabular}




\subsection{Model application at the Salsola and Carapelle watersheds in the long-term}

Calibrated parameters were used for the application at Carapelle (period 19861996) and Salsola (1970-1984) watersheds in order to test the model for the long-term. Comparison between simulated and observed runoff data in both the watersheds is reported in figures 5-6. Statistical parameters, that were calculated for each simulation $\left(\mathrm{R}^{2}=0.6, \mathrm{NSE}=0.7\right.$ for the Carapelle and $\mathrm{R}^{2}=0.6, \mathrm{NSE}=0.7$ for the Salsola), point out that simulated runoff are in good agreement when compared with the observed watersheds response. Yearly sediment loads were calculated from complete monthly series. Sediment load modelling indicates simulated values are consistent with the recorded ones, fig. 7 . This means that the modelling process is efficient for small and medium size watersheds when adequate meteorological, soil and crop data are available.

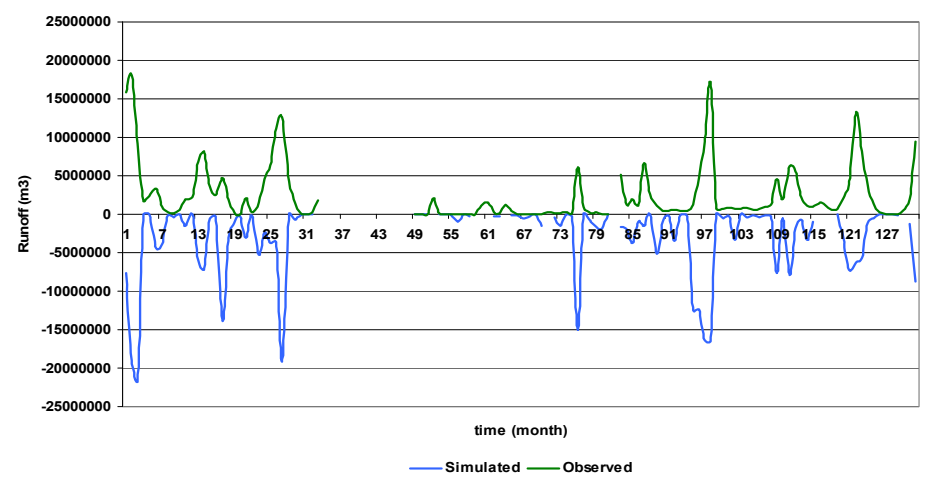

Figure 5: Runoff prediction of the AnnAGNPS model for the Carapelle watershed. In the upper part of the graph there are the observed runoffs, in the lower part the simulated ones.

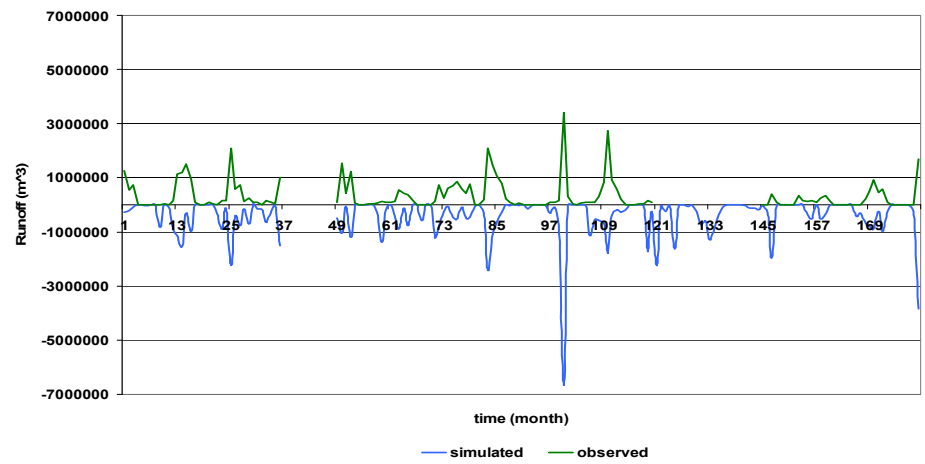

Figure 6: Runoff prediction of the AnnAGNPS model for the Salsola watershed. In the upper part of the graph there are the observed runoffs, in the lower the simulated ones. 


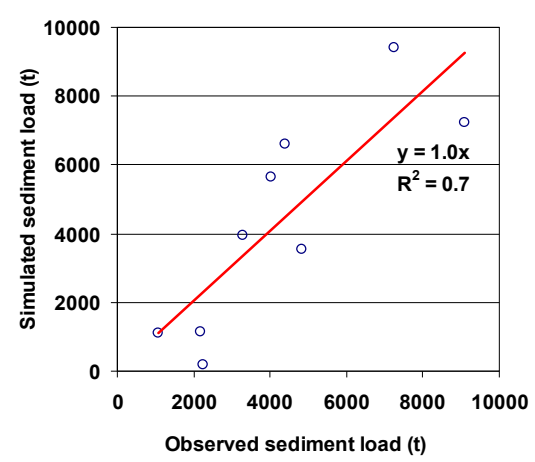

Figure 7: Yearly sediment load prediction of AnnAGNPS for the Salsola watershed.

\section{Conclusions}

In this paper the results of sediment transport modelling in Northern Apulia torrents are reported.

AnnAGNPS is a continuous simulation watershed-scale model for peak flow, runoff, sediment load and pollutants prediction. The model is very sensitive to storm type, $\mathrm{CN}$ values and to rooting density, surface residue and crown canopy cover associated with the $\mathrm{C}$ factor, so the application in uncalibrated mode can determine high average errors in predictions.

The AnnAGNPS model was calibrated and validated in the Carapelle watershed using twelve flood events. Very good performances were obtained by the model in simulating peak flow, runoff and sediment load which is mainly triggered by the field operations and by precipitation events.

Calibrated parameters were used to evaluate the model in the long-term using ten years of runoff data. Good correlation and agreement between simulated and observed data at both time scales allows one to use the model for studying sediment transport dynamics and for watershed management and prediction in ungaged basins having the same characteristics.

The long-term application at Carapelle watershed was compared to that of Salsola sub-catchment in order to test the influence of different spatial scales in modelling. The model has predicted the runoff volume within the range of good accuracy and this indicates that the SCS curve number method used in the AnnAGNPS model is suitable for runoff volume prediction. Simulated sediment loads values were compared with measurements showing a good agreement in the general pattern.

\section{References}

[1] Beasley, D.B., Huggins, L.F. \& E.J. Monke, ANSWERS: a model for watershed planning. Trans. ASAE 23 (4), pp. 938-944, 1980. 
[2] Knisel, W.G., CREAMS: A Fieldscale Model for Chemical, Runoff, and Erosion from Agricultural Management Systems. USDA, Science and Education Administration, Conservation Report No. 26, Washington, D.C., 1980.

[3] Leonard, R.A., Knisel, W.G., \& Still, D.A., GLEAMS: Groundwater Loading Effects of Agricultural Management Systems. Transactions of ASAE, vol. 30, pp. 1403-1418, 1987.

[4] Bingner, R. L. \& Theurer F.D. AGNPS Web Site, 2009. http://www.ars.usda.gov/Research/docs.htm?docid=5199

[5] Arnold, G., Srinavasan, R., Muttiah, R.S., \& Williams, J.R., Large Area Hydrologic Modeling and Assessment. Part I. Model Development, Journal of the American Water Resources Association, vol. 34, pp. 73-89, 1998.

[6] Mishra, S. K. \& Singh, V. P., Soil Conservation Service Curve Number (SCS-CN) Methodology. Series: Water Science and Technology Library, Vol.42, pp.536, Hardcover 2003.

[7] Walling, D.E., He, Q. \& Whelan, P. A., Using 137Cs measurements to validate the application of the AGNPS and ANSWERS erosion and sediment yield models in two small Devon catchments. Soil and Tillage Research, Volume 69, Issues 1-2, pp. 27-432003.

[8] Parajuli, P. B., Nelson, N. O., Frees, L. D. \& Mankin, K. R., Comparison of AnnAGNPS and SWAT model simulation results in USDA-CEAP agricultural watersheds in south-central Kansas. Hydrological Processes, 23(5), pp. 748-763.

[9] Yuan, Y., Bingner, R. L. \& Rebich, R. A., Evaluation of AnnAGNPS on Mississippi Delta MSEA Watersheds. Trans. of the ASAE, Vol. 44(5): 1183-1190, 2001.

[10] Theurer, F.D. \& Clarke, C.D., Wash load component for sediment yield modeling. In Proceedings of the Fifth Federal Interagency Sedimentation Conference, March 18-21, 1991, Las Vegas, NV: Subcommittee on Sedimentation of the Interagency Advisory Committee on Water Data, Vol. 1, pp. 7-1 to 7-8.

[11] Caliandro, A., Lamaddalena, N., Stellati, M. \& Seduto, P., Caratterizzazione agroecologica della Regione Puglia. In Funzione della potenzialità produttiva: Progetto Acla 2. Puglia, Bari, 2005.

[12] Mouelhi, S., Michel, C., Perrin, C., \& Andreassian, V., Stepwise development of a two-parameter monthly water balance model, Journal of Hydrology, 318, pp. 200-21, 2006.

[13] Eckhardt, K., How to construct recursive digital filters for baseflow separation. Hydrological Processes 19, 507-515, 2005.

[14] Kyoung, J. L., Jong-Gun, K., Bernie, E., Ji-Hong, J., Younshik, P., YongChul, S., Sung-Gu, H., Ki-Sung, K., Joongdae, C., \& Dong Sun, Y., Development of Optimization Module in the WHAT System for Accurate Hydrograph Analysis and Model Application. ASAE Annual Meeting. www.asabe.org. 2007.

[15] Gentile, F., Bisantino, T., Corbino, R., Milillo, F., Romano, G., \& Trisorio Liuzzi G. Monitoring and analysis of suspended sediment transport 
dynamics in the Carapelle torrent (southern Italy). Catena 80, pp. 1-8, 2009.

[16] Ferro, V., Porto, P., \& Yu, B., A comparative study of rainfall erosivity estimation for southern Italy and southeastern Australia, Hydrol. Sci. Journal-des Sciences Hydrologiques 44, pp. 3-23, 1999.

[17] Lal, R., \& Elliot, W., Erodibility and erosivity. In: Lal R. (Ed.), Soil Erosion Research Methods. Soil and Water Conservation Society and St. Lucie Press. USA. pp. 181-208, 1994.

[18] Saxton, K.E., \& Rawls, W.J., Soil water characteristic estimates by texture and organic matter for hydrologic solutions, Soil Sci. Soc. Am. J., 70, 1569-1578, 2006.

[19] Chouaib, W., Evaluation of Annualized Agricultural Non Point Source model (AnnAGNPS) for runoff, peak flow and sediment yield estimations in the Carapelle watershed, Apuglia Region (Southern Italy). Master of Science Thesis on Land and Water Resources Management: Irrigated Agriculture. International Centre for Advanced Mediterranean Agronomic Studies (CIHEAM-Bari Italy), 2009. 